\title{
Vitamin D analogue EB1089-induced prostate regression is associated with increased gene expression of insulin-like growth factor binding proteins
}

\author{
T Nickerson and H Huynh \\ Lady Davis Institute for Medical Research, McGill University, 3755 Cote Ste Catherine Road, Montreal, Quebec, Canada H3T 1E2 \\ (Requests for offprints should be addressed to H Huynh)
}

\begin{abstract}
Vitamin D analogues have an antiproliferative effect on prostate cancer cells in vitro and thus have been proposed as candidates for chemoprevention of prostate cancer. Insulin-like growth factor (IGF)-I has been shown to protect cells from apoptosis and plays an essential role in normal prostate physiology. We have studied the effects of the 1,25-dihydroxyvitamin $\mathrm{D}_{3}$ analogue EB1089 on the IGF system in the prostate in vivo. Treatment of rats with EB1089 for 14 days caused a 25\% decrease in ventral prostate weight. Apoptosis was detected in prostate sections of EB1089-treated rats by terminal deoxynucleotidyl transferase-mediated dUTP nick end labeling (TUNEL) assay and histologic examination of hematoxylin/ eosin stained tissue sections indicated that secretory epi-
\end{abstract}

thelial cells were flattened, a characteristic of cells undergoing pressure-induced atrophy. Ventral prostate regression was associated with 15- to 25-fold increases in gene expression of IGF-binding proteins (IGFBPs) $-2,-3,-4$ and -5 . We also observed a 40 -fold increase in prostatic IGF-I mRNA levels in response to EB1089. Although we have previously shown that castration of rats leads to upregulation of IGFBPs in the ventral prostate, EB1089 treatment had no effect on serum levels of dihydrotestosterone or free testosterone. These results suggest that prostate regression induced by EB1089 may be related to alterations in availability of IGF-I as a result of increased production of IGFBPs.

Journal of Endocrinology (1999) 160, 223-229

\section{Introduction}

Prostate cancer is the most common malignancy in men (Garraway \& Alexander 1997). In North America, nearly all men develop histologic benign prostate hyperplasia and at least $10 \%$ will be diagnosed with prostate cancer (Droller 1997). There is evidence that restricted exposure to sunlight, which is necessary for vitamin D production in the body, is correlated with increased mortality from prostate cancer, suggesting a role for vitamin $\mathrm{D}$ in the prevention of prostate cancer (Schwartz \& Hulka 1990, Hanchette \& Schwartz 1992).

The biologically active form of vitamin D, 1,25dihydroxyvitamin $\mathrm{D}_{3}\left(1,25(\mathrm{OH})_{2} \mathrm{D}_{3}\right.$ or calcitriol), has antiproliferative and differentiating effects on both normal and prostate cancer cells which have been demonstrated in vitro and in vivo (Schwartz et al. 1995, Skowronski et al. 1995). The effects of $1,25(\mathrm{OH})_{2} \mathrm{D}_{3}$ are mediated by the vitamin $\mathrm{D}$ receptor, which is a member of the nuclear steroid hormone receptor family (Baker et al. 1988). Vitamin D receptors are found in normal and cancerous prostate tissue and cell lines (Feldman et al. 1995). The use of $1,25(\mathrm{OH})_{2} \mathrm{D}_{3}$ clinically as an antiproliferative agent is limited by the hypercalcemia associated with high dose administration. Calcitriol analogues have been developed that mimic the antiproliferative effects of $1,25(\mathrm{OH})_{2} \mathrm{D}_{3}$, but have little effect on calcium homeostasis (Schwartz et al. 1994). These compounds are currently considered as candidates for prevention and/or treatment of benign prostate hyperplasia and prostate cancer (Campbell \& Koeffler 1997).

Insulin-like growth factor I (IGF-I) is required for the survival of human prostate epithelial cells in vitro and plays an essential role in normal prostate physiology (Peehl et al. 1996). A recent prospective study revealed a strong positive association between serum IGF-I levels and prostate cancer risk (Chan et al. 1998). The well recognized mitogenic and antiapoptotic effects of IGF-I are mediated through binding to the IGF-I receptor (Baserga 1995). Observations that IGF-binding protein (IGFBP)-3 inhibits IGF-induced proliferation of normal prostate epithelial cells (Cohen et al. 1991) and that serum levels of certain IGFBPs are changed in patients with prostate cancer (Cohen et al. 1993, Kanety et al. 1993), suggest that IGFBPs (reviewed in Clemmons 1997) are important modulators of IGF activity in the human prostate.

Previous studies have demonstrated the efficacy of the synthetic calcitriol analogue, EB1089 (Leo 
Pharmaceuticals, Ballerup, Denmark) in reducing growth of prostate cancer cells (deVos et al. 1997, Wang et al. 1997). We have shown that the growth inhibitory effects of EB1089 are associated with increased IGFBP expression in both MCF7 breast cancer cells (Rozen et al. 1997) and PC-3 prostate cancer cells (Huynh et al. 1998). While IGFs have been recognized as antiapoptotic factors for some time, it has only recently been demonstrated that IGFBPs can regulate apoptosis in vitro (Nickerson et al. 1997, Rajah et al. 1997) and are associated with prostate regression induced by castration (Nickerson et al. 1998). We undertook these experiments to study the effects of EB1089 on IGFBP gene expression in the normal prostate in vivo.

\section{Materials and Methods}

\section{Animals}

All animal studies were conducted in accordance with local humane animal care standards. EB1089 (Leo Pharmaceuticals) was supplied at a concentration of $0.1 \mathrm{mg} / \mathrm{ml}$ in propylene glycol with $0.05 \mathrm{M} \mathrm{Na}_{2} \mathrm{HPO}_{4}$. Male Sprague-Dawley rats ( $n=9$ per group) weighing $\sim 475 \mathrm{~g}$ (Charles River, Montréal, Québec) received i.p. injections of 0, 1, 2 or $3 \mu \mathrm{g}$ EB1089 per kg body weight, which was prepared fresh by diluting stock solution in propylene glycol, every second day for 2 weeks. Animals were killed on day 14 and the ventral prostate was collected and weighed. Part of the tissue was fixed in 10\% buffered formalin, embedded in paraffin and cut into $5 \mu \mathrm{m}$ sections. Sections were stained with hematoxylin/eosin for histologic examination. The remaining prostate tissue was immediately frozen in liquid nitrogen for RNA extraction. Serum was collected from animals prior to killing and radioimmunoassay (RIA) was performed to measure levels of free testosterone (T) (Diagnostic Products Corporation, Los Angeles, CA, USA) and dihydrotestosterone (DHT) (Diagnostic Biochem Canada, London, Ontario, Canada) according to the manufacturer's directions. The intra- and interassay variabilities of these assays are 7 and $8 \cdot 1 \%$ respectively.

\section{Northern blot analysis}

Total RNA was isolated from tissue using the RNAzol B method (Teltest, Friendswood, TX, USA). Total RNA $(50 \mu \mathrm{g})$ was fractionated on $1 \%$ agarose gels and transferred onto Zeta-Probe membrane (Bio-Rad, Mississauga, Ontario, Canada) in $50 \mathrm{mM} \mathrm{NaOH}$. The cDNAs for IGFBPs $-2,-3,-4$ and -5 (Shimasaki \& Ling 1991) and IGF-I (Murphy et al. 1987) were labeled with $\left[\alpha{ }^{32} \mathrm{P}\right] \mathrm{dCTP}$ using T7 Quick-Prime kit (Pharmacia, Baie D’Urfe, Quebec, Canada). Prehybridization, hybridization and washing were performed as previously described
(Nickerson et al. 1998). Blots were subjected to autoradiography with intensifying screen at $-80{ }^{\circ} \mathrm{C}$. Quantitative analysis of gene expression was accomplished by averaging densitometric scanning of three autoradiograms per gene and results were corrected for minor loading differences by normalizing to $28 \mathrm{~S}$ rRNA.

\section{Quantitation of apoptosis}

Apoptosis was detected in formalin-fixed, paraffin embedded tissue sections using the ApoAlert DNA fragmentation assay (Clontech, Palo Alto, CA, USA), which is based on the terminal deoxynucleotidyl transferasemediated dUTP nick end labeling (TUNEL) method. Five micrometer sections were prepared and treated according to the manufacturer's instructions. Apoptosis was visualized and photographed under a fluorescent microscope equipped with an FITC filter. Labeling indices were obtained by counting the number of labeled cells among at least 100 epithelial cells per region and expressed as percentage values.

\section{Results}

Ventral prostate regression induced by EB1089

We observed a $25 \%$ decrease in ventral prostate weight in rats treated daily with EB1089 compared with control animals (Fig. 1A). The reduction in ventral prostate weight at 2 weeks was similar in rats receiving 1, 2 or $3 \mu \mathrm{g}$ EB1089 per kg body weight and was not related to changes in mean body weight, which for all treatment groups was $<4 \%$ of total body weight (data not shown). Ventral prostate regression most commonly occurs as a result of androgen deprivation. To determine whether the mechanism of EB1089-induced prostate regression involves alteration of androgen effects, we measured androgen levels in the serum of EB1089-treated rats. EB1089 had no effect on serum levels of free T or DHT in rats treated for 2 weeks (Fig. 1B).

Effect of EB1089 on morphology and apoptosis of rat ventral prostate

Ventral prostate sections from rats treated with $2 \mu \mathrm{g}$ EB1089 per kg body weight every second day for 2 weeks were stained with hematoxylin and eosin for assessment of general morphology. In the normal rat prostate (Fig. 2A), a thick layer of tall columnar secretory epithelial cells lines the lumen of the prostate. In rats treated with $2 \mu \mathrm{g}$ EB1089, the epithelial layer is flattened (Fig. 2B), consistent with cytoplasmic condensation characteristic during prostate regression (Tenniswood 1997). Also, as can be seen in Fig. 2, we observed a large accumulation of material in the lumen of EB1089-treated prostates. We 
A

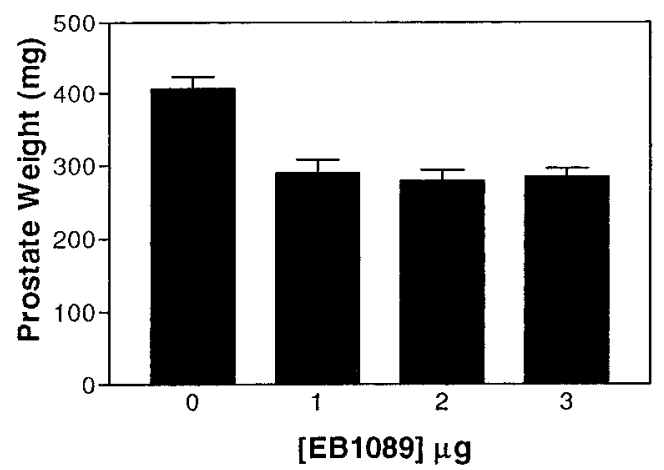

B

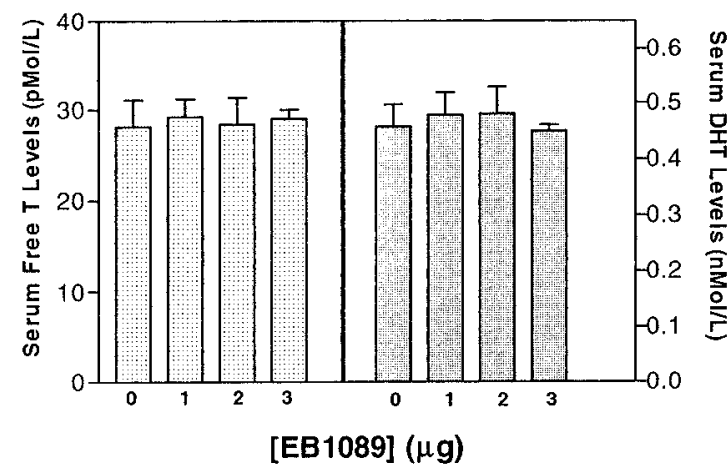

Figure 1 Ventral prostate regression and serum androgen levels in rats treated with the vitamin D analogue, EB1089. Rats were treated with 0, 1, 2 or $3 \mu \mathrm{g}$ EB1089 per kg body weight every second day for 2 weeks as described in Materials and Methods. The ventral prostate was excised, carefully trimmed to remove all connective tissue and weighed. Ventral prostate weights are plotted as mean weight $(\mathrm{mg}) \pm$ S.E.M. (A). The ventral prostate weights of rats treated with EB1089 were statistically different from those of control animals $(P<0 \cdot 05)$ as determined by MannWhitney U-test. Serum levels of free T and DHT were measured by RIA and plotted as mean concentration \pm S.E.M. (B).

performed TUNEL assays on ventral prostate sections to detect apoptotic cell death. In the normal rat prostate, the rate of apoptosis is very low (Fig. 2C), in keeping with prior reports that apoptosis occurs in $\sim 2 \%$ of cells in the rat ventral prostate and is balanced by cell proliferation (Isaacs 1984). In rats treated with $2 \mu \mathrm{g}$ EB1089, 80\% of epithelial cells are apoptotic (Fig. 2D). The rates of apoptosis for rats treated with 1 and $3 \mu \mathrm{g}$ EB1089 were $\sim 50$ and $\sim 70 \%$ respectively.

\section{Effect of EB1089 on IGFBP and IGF-I gene expression in the ventral prostate}

We have previously shown that castration-induced apoptosis in the rat ventral prostate is associated with increased expression of IGFBPs (Nickerson et al. 1998). Therefore, we used Northern analysis to determine if EB1089-induced prostate regression is associated with changes in IGF physiology. Administration of EB1089 resulted in dose-dependent increases in expression of IGFBPs-2, $-3,-4$ and -5 in the ventral prostate. IGFBP-4 mRNA levels increased 3-fold in prostate of rats receiving $1 \mu \mathrm{g}$ EB1089 and 25-fold in animals receiving $2 \mu \mathrm{g}$ EB1089 compared with control animals (Fig. 3A). Similarly, IGFBP-5 mRNA levels increased 2- and 20-fold respectively in the 1- and 2- $\mu \mathrm{g}$ EB1089 groups compared with control (Fig. 3A). Treatment with $1 \mu \mathrm{g}$ EB1089 caused a 5-fold increase in IGFBP-2 mRNA levels and $2 \mu \mathrm{g}$ EB1089 resulted in a 17-fold increase compared with control (Fig. 3B). Prostatic IGFBP-3 gene expression increased $2-$ and 15-fold in rats treated with 1 and $2 \mu \mathrm{g}$ EB1089 respectively (Fig. 3B). IGF-I gene expression in ventral prostate is 10 -fold higher than control in rats treated with $1 \mu \mathrm{g}$ EB1089 and 40-fold higher than control in rats treated with $2 \mu \mathrm{g}$ EB1089 (Fig. 4B). All increases in IGF-I and IGFBP gene expression in treatment groups compared with control groups were statistically significant $(P<0 \cdot 05)$ as determined by Mann-Whitney U-test.

\section{Discussion}

In this in vivo study, we have demonstrated that the calcitriol analogue, EB1089, significantly reduces ventral prostate weight in normal rats. Prostate regression was associated with apoptotic cell death and gene expression of IGFBPs. Minimal body weight loss was observed $(<20 \mathrm{~g}$ of $475 \mathrm{~g}$ total body weight) in animals treated with various doses of EB1089, in keeping with previous studies which reported no hypercalcemia or weight loss in rats administered comparable doses of EB1089 (Colston et al. 1992). Vitamin D receptor levels in the rat ventral prostate did not change significantly in response to treatment with EB1089, as measured by western blot analysis (data not shown). Histologic examination indicated a reduction in the epithelial component of the prostate, and TUNEL analysis confirmed apoptotic death of prostate epithelial cells. Others have reported antiproliferative effects of $1,25(\mathrm{OH})_{2} \mathrm{D}_{3}$ on both normal prostate epithelial and stromal cells in vitro, although in vivo evidence suggests that inhibitory effects of $1,25(\mathrm{OH})_{2} \mathrm{D}_{3}$ may be limited to epithelial cells (Peehl et al. 1994, Konety et al. 1996). In our system, net reduction of prostate weight can be contributed to selective loss of epithelial cells, even if EB1089 has little or no effect on the stromal component. Although prostate weight was significantly reduced by treatment with EB1089, there was no correlation between dose of EB1089 and total weight reduction. The accumulation of secretory materials, which was found in prostates from all EB0189-treated animals, may account for the absence of differences in prostate weight between the various EB1089 groups.

The mechanism by which $1,25(\mathrm{OH})_{2} \mathrm{D}_{3}$ inhibits growth of cancer cells is largely unknown. In this study we have shown that reduction of ventral prostate weight by 
A

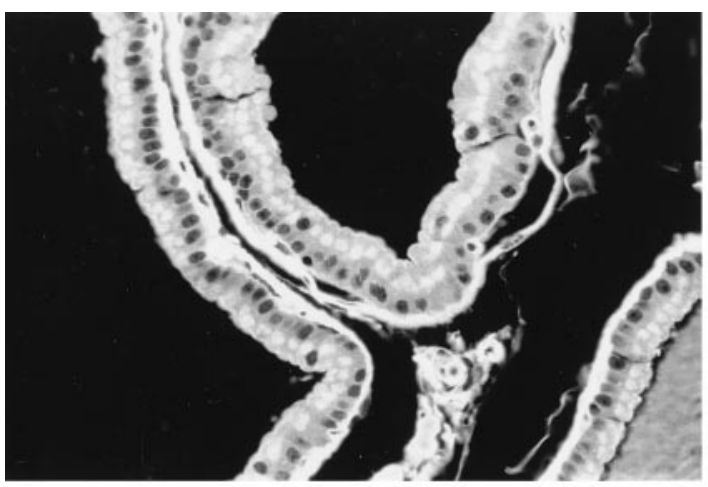

B

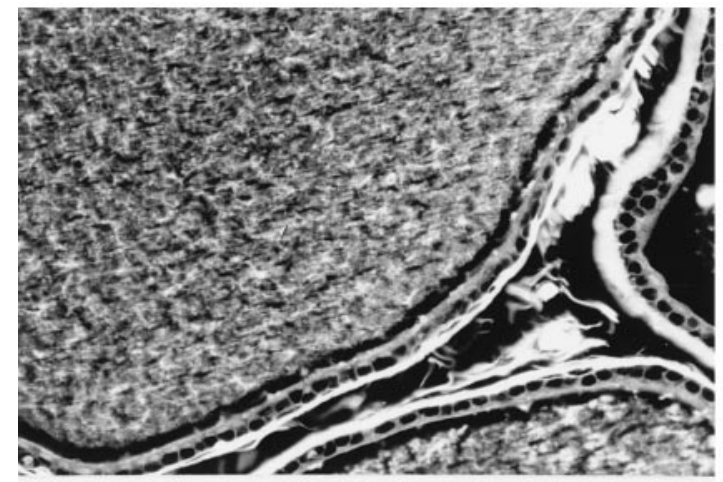

C

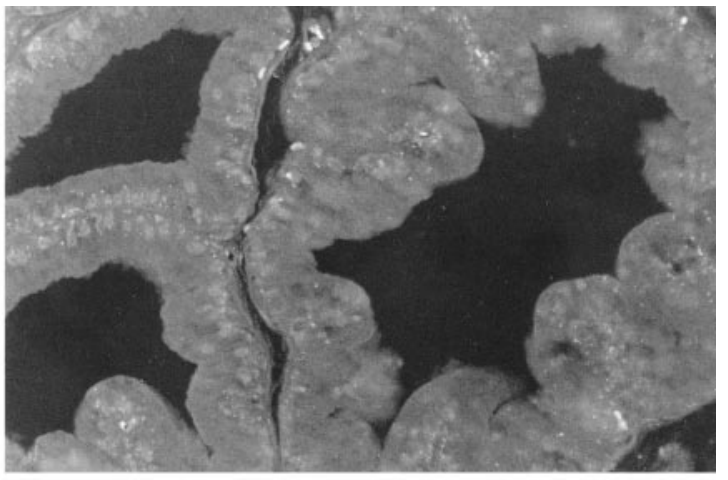

D

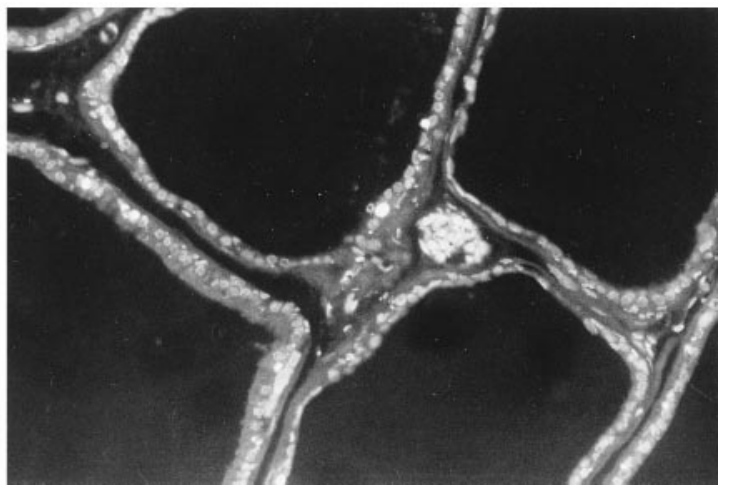

Figure 2 Effects of EB1089 on morphology and apoptosis of rat ventral prostate. Formalin-fixed, paraffin-embedded ventral prostate tissue sections were stained with hematoxylin and eosin for histologic examination. Shown are the ventral prostates of rats treated for 2 weeks with vehicle alone (A) or $2 \mu \mathrm{g}$ EB1089 (B). The TUNEL method was used to detect ventral prostate apoptosis in situ. The sections were photographed using an FITC filter in a fluorescence microscope at a magnification of 320X. The nuclei of apoptotic cells contain fluorescein-labeled DNA and appear bright. Shown are prostate sections of rats treated with either vehicle alone (C) or $2 \mu \mathrm{g}$ EB1089 (D).

EB1089 is associated with changes in IGF physiology. This is not surprising, as it has been recognized for some time that IGFs have a central role in regulating proliferation and apoptosis of prostate epithelial cells (Cohen et al. 1991, Baserga 1995). However, more attention has been given recently to the apoptotic effects of IGFBPs. It has been hypothesized that IGFBPs trigger apoptosis in the prostate following androgen ablation (Guenette \& Tenniswood 1994). In keeping with this hypothesis, we have recently reported that castration-induced apoptosis in the rat ventral prostate involves increased expression of IGFBPs (Nickerson et al. 1998). Furthermore, there is evidence that IGFBP-3 induces apoptosis in PC-3 prostate cancer cells (Rajah et al. 1997) and that the antiproliferative effects of EB1089 on PC-3 cells are mediated at least in part by increased expression of IGFBP-3 (Huynh et al. 1998). We demonstrate here that prostate regression in vivo induced by EB1089 is associated with increased expression of genes encoding IGFBPs and IGF-I. Castration causes a rapid decrease in serum $T$ levels and a corresponding decrease in prostate DHT concentration which leads to the death of androgen-dependent cells within the prostate and results in involution of the gland
(Kyprianou \& Isaacs 1988). However, no changes were observed in serum levels of free T or DHT in rats treated with EB1089, indicating that prostate regression and induction of IGFBPs in the prostate are independent of androgen effects. These results emphasize the potential significance of IGFBPs during prostate involution and raise the possibility that IGFBPs, rather than being strictly under androgen control, are more generally expressed during physiologic situations which trigger apoptosis.

In rat ventral prostate, IGF-I is secreted by stromal cells, while epithelial cells which respond to IGF-I express IGF-I receptors. IGFBPs which mediate the interaction between IGF-I and its receptor are mainly produced by epithelial cells, although some are also expressed by stromal cells (Steiner 1995). Rapid induction of IGFBPs may sequester IGF-I away from the IGF-I receptor (Guenette \& Tenniswood 1994). In support of this view, we observed upregulation of IGF-I gene expression in prostates of EB1089-treated animals which may result from loss of IGF-I feedback inhibition on its own gene as reported previously (Conover et al. 1989). Alternatively, there is evidence that IGFBP-3 has IGF-independent effects on cell growth and survival that are mediated by a 

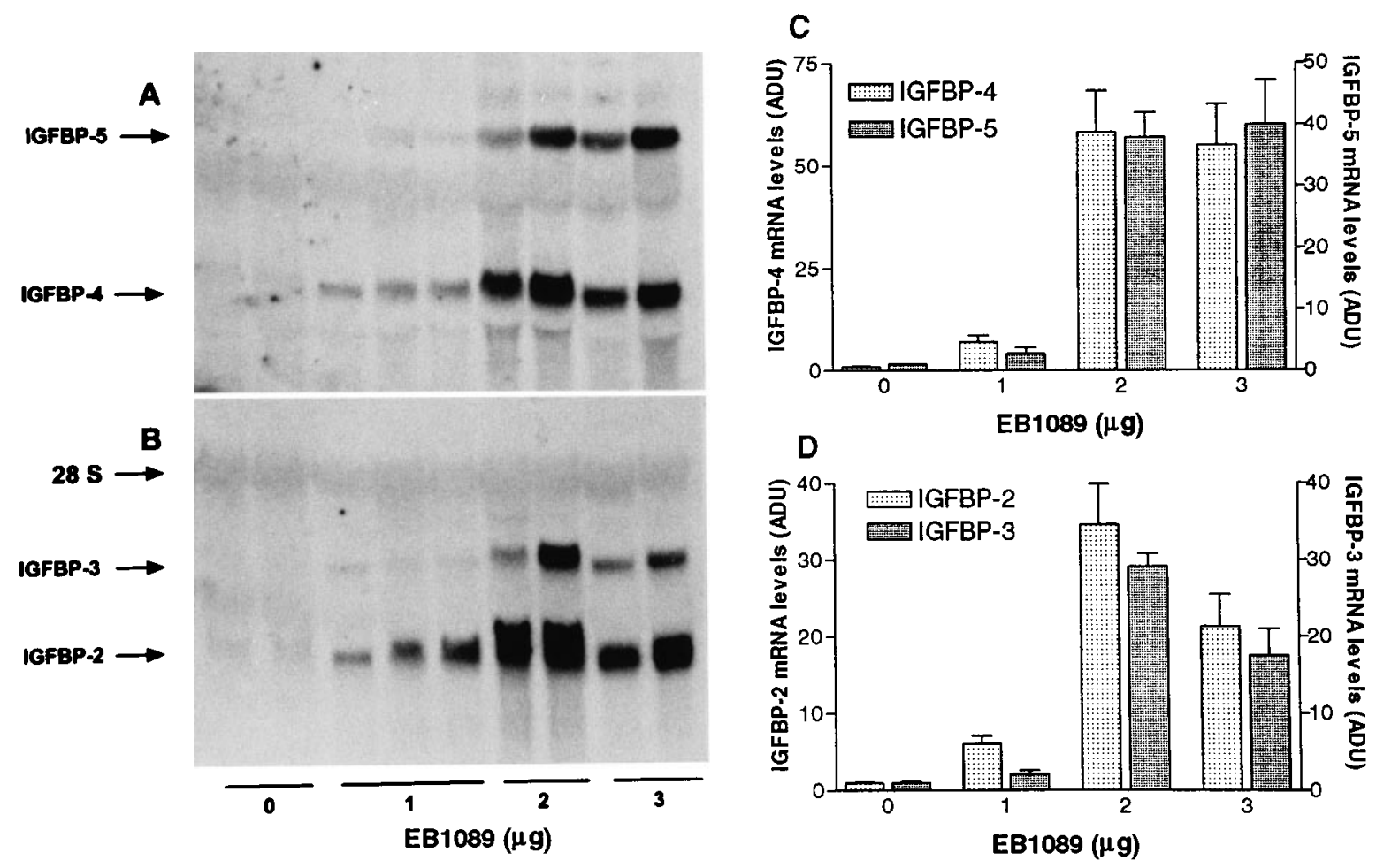

Figure 3 Expression of IGFBPs in the rat ventral prostate during treatment with the vitamin D analogue EB1089. The $2 \cdot 4$ and $6 \cdot 0 \mathrm{~kb}$ mRNAs for IGFBPs-4 and -5 respectively were detected by Northern blot analysis in ventral prostate of rats treated with the indicated doses of EB1089 (A). The filter was stripped and re-probed to detect the $2.6 \mathrm{~kb}$ IGFBP-3 and $1.4 \mathrm{~kb}$ IGFBP-2 mRNA (B). Each lane contains RNA pooled from three individual animals. Expression of IGFBP genes was quantitated by densitometric scanning of three autoradiograms and lanes from each treatment group were averaged and are expressed as mean arbitrary density units $(A D U) \pm$ S.E.M. $(C, D)$.

putative IGFBP-3 receptor (Oh et al. 1993, Rajah et al. 1997). These mechanisms are not mutually exclusive however, as direct IGFBP-3 effects and reduction of IGF-I resulting from interactions between IGF-I and IGFBPs-2, -4 or -5 could occur simultaneously. The net effect, regardless of which mechanism is involved, seems to be loss of survival signals and activation of programmed cell death. To further elucidate the role of IGFBPs in apoptosis, it will be necessary to examine interactions at the protein level, but such studies must await the availability of suitable antibodies against rat IGFBPs.

Androgen deprivation is the strategy most commonly employed in the management of prostate cancer. Initially, primary prostate cancer and metastatic sites will respond to androgen ablation therapy; however, in most cases the disease progresses within 3-5 years when populations of hormone-refractory cells emerge (Droller 1997). EB1089 has antiproliferative effects in both androgen-responsive LNCaP prostate cancer cells and androgen-independent PC-3 cells (Skowronski et al. 1995, Blutt et al. 1997). Vitamin D analogues, or other novel approaches that target IGF bioactivity, may provide a second-line therapeutic strategy for targeting IGF-stimulated prostate cancer proliferation when androgen deprivation fails. It will be of interest in this respect to compare the effects of EB1089 on growth of androgen responsive versus independent prostate tumors in vivo.

Our observation that EB1089 results in accumulation of material in the prostate lumen, as well as compression of the epithelial cell layer, raises the possibility that increased pressure in the lumen contributes to the mechanism of EB1089-induced prostate regression. There may be parallels between this phenomenon in the prostate and the pressure-induced atrophy of mammary gland epithelial cells during post-lactational involution (Li et al. 1997). Accumulation of milk in the rat mammary gland activates gene expression of IGFBPs-4 and -5 , and has been shown to contribute to apoptosis of mammary epithelial cells and involution of the gland (Tonner et al. 1995). It will be of interest in future studies to search for other compounds which have a similar effect on the prostate in order to further understand the nature of the accumulated material in the lumen and its role, if any, in prostate regression.

In summary, we show here that reduction of ventral prostate weight by EB1089 involves changes in IGF physiology. Based on these in vivo results, together with 

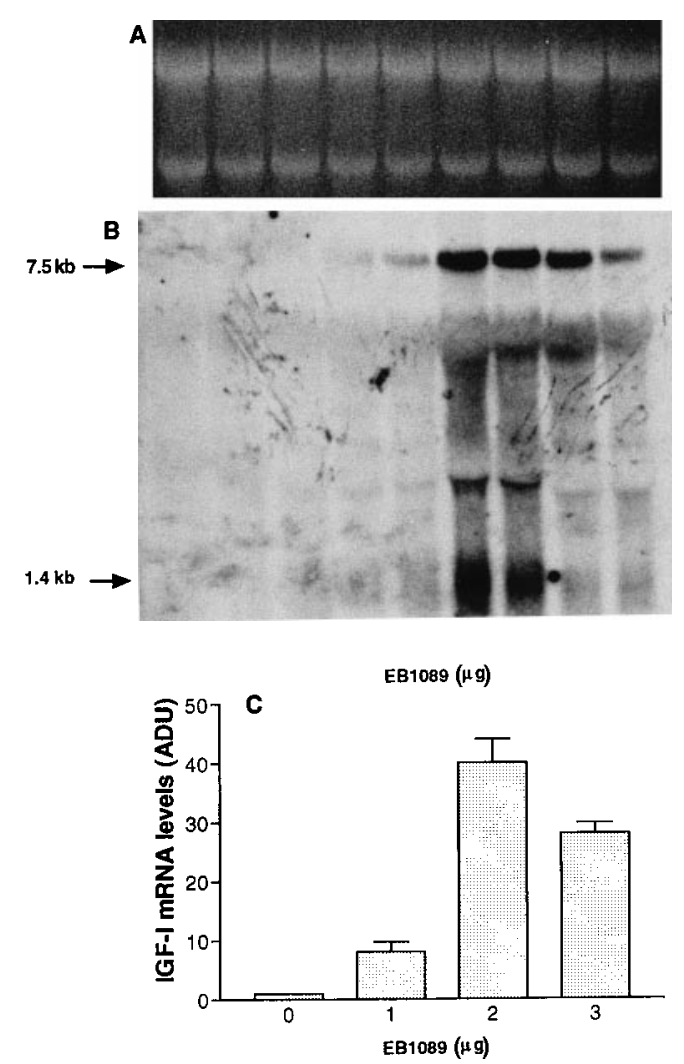

Figure 4 Effects of EB1089 on IGF-I gene expression in the rat ventral prostate. One representative filter was used for all Northern blots shown, and ethidium bromide staining of the agarose gel is shown (A). IGF-I mRNA transcripts were detected by Northern blot analysis (B). For each lane, the sum of the density bands corresponding to IGF-I transcripts was calculated. These sums were averaged for all lanes corresponding to each treatment group from three autoradiograms and are expressed as mean arbitrary density units (ADU) \pm S.E.M. (C).

in vitro findings, we hypothesize that the mechanism of EB1089-induced prostate regression may involve pressure atrophy and increased expression of IGFBPs.

\section{Acknowledgements}

We would like to thank Dr Lise Binderup, Leo Pharmaceuticals for providing EB1089 and Dr S Shimasaki for IGFBP cDNAs.

\section{References}

Baker AR, McDonnell DP, Hughes M, Crisp TM, Mangelsdorf DJ, Haussler MR, Pike JW, Shine J \& O'Malley BW 1988 Cloning and expression of full-length cDNA encoding human vitamin D receptor. Proceedings of the National Academy of Sciences of the USA 85 3294-3298.
Baserga R 1995 The insulin-like growth factor-I receptor: a key to tumor growth? Cancer Research 55 249-252.

Blutt SE, Allegretto EA, Pike JW \& Weigel NL 1997 1,25dihydroxyvitamin $\mathrm{D}_{3}$ and 9-cis-retinoic acid act synergistically to inhibit the growth of LNCaP prostate cells and cause accumulation of cells in $\mathrm{G}_{1}$. Endocrinology 138 1491-1497.

Campbell MJ \& Koeffler HP 1997 Toward therapeutic intervention of cancer by vitamin D compounds. Journal of the National Cancer Institute 89 182-185.

Chan JM, Stampfer MK, Giovannucci E, Gann PH, Ma J, Wilkinson P, Hennekens CH \& Pollak M 1998 Plasma insulin-like growth factor-I and prostate cancer risk: a prospective study. Science $\mathbf{2 7 9}$ 563-566.

Clemmons DR 1997 Insulin-like growth factor binding proteins and their role in controlling IGF actions. Cytokine and Growth Factor Reviews 8 45-62.

Cohen P, Peehl DM, Lamson G \& Rosenfeld RG 1991 Insulin-like growth factors (IGFs), IGF receptors, and IGF-binding proteins in primary cultures of prostate epithelial cells. Journal of Clinical Endocrinology and Metabolism 73 401-407.

Cohen P, Peehl DM, Stamey TA, Wilson KF, Clemmons DR \& Rosenfeld RG 1993 Elevated levels of insulin-like growth factorbinding protein-2 in the serum of prostate cancer patients. Journal of Clinical Endocrinology and Metabolism 76 1031-1035.

Colston KW, Mackay AG, James SY, Binderup L, Chander S \& Coombes RC 1992 EB1089: a new vitamin D analogue that inhibits the growth of breast cancer cells in vivo and in vitro. Biochemical Pharmacology 44 2273-2280.

Conover CA, Liu F, Powell D, Rosenfeld RG \& Hintz RL 1989 Insulin-like growth factor-binding proteins from cultured human fibroblasts. Characterization and hormonal regulation. Journal of Clinical Investigation 83 852-859.

Droller MJ 1997 Medical approaches in the management of prostate disease. British Journal of Urology 79 42-52.

Feldman D, Skowronski RJ \& Peehl DM 1995 Vitamin D and prostate cancer. Advances in Experimental Medicine and Biology 375 53-63.

Garraway WM \& Alexander FE 1997 Prostate disease: epidemiology, natural history and demographic shifts. British Journal of Urology $\mathbf{7 9}$ 3-8.

Guenette RS \& Tenniswood M 1994 The role of growth factors in the suppression of active cell death in the prostate: an hypothesis. Biochemistry and Cell Biology 72 553-559.

Hanchette CL \& Schwartz GG 1992 Geographic patterns of prostate cancer mortality. Cancer 70 2861-2869.

Huynh H, Pollak M \& Zhang J-C 1998 Regulation of insulin-like growth factor (IGF)-II and IGF-binding protein-3 autocrine loop in human PC-3 prostate cancer cells by vitamin D metabolite $1,25(\mathrm{OH})_{2} \mathrm{D}_{3}$ and its analog EB1089. International Journal of Oncology 13 137-143

Isaacs JT 1984 Antagonistic effect of androgen on prostatic cell death. Prostate 5 547-557.

Kanety H, Madjar Y, Dagan Y, Levi J, Papa MZ, Pariente C, Goldwasser B \& Karasik A 1993 Serum insulin-like growth factorbinding protein-2 (IGFBP-2) is increased and IGFBP-3 is decreased in patients with prostate cancer: correlation with serum prostatespecific antigen. Journal of Clinical Endocrinology and Metabolism $\mathbf{7 7}$ 229-233.

Konety BR, Schwartz GG, Acierno JS, Becich MJ \& Getzenberg RH 1996 The role of vitamin D in normal prostate growth and differentiation. Cell Growth and Differentiation 7 1563-1570.

Kyprianou N \& Isaacs JT 1988 Activation of programmed cell death in the rat ventral prostate after castration. Endocrinology 122 552-562.

Li M, Liu X, Robinson G, Bar-Peled U, Wagner K-U, Young WS, Hennighausen L \& Furth PA 1997 Mammary-derived signals 
activate programmed cell death during the first stage of mammary gland involution. Proceedings of the National Academy of Sciences of the USA 94 3425-3430.

Murphy LJ, Bell GI, Duckworth ML \& Friesen HG 1987 Identification, characterization, and regulation of a rat complementary deoxyribonucleic acid which encodes insulin-like growth factor-I. Endocrinology 121 684-691.

Nickerson T, Huynh H \& Pollak M 1997 Insulin-like growth factorbinding protein-3 induces apoptosis in MCF7 breast cancer cells. Biochemical and Biophysical Research Communications 237 690-693.

Nickerson T, Pollak M \& Huynh H 1998 Castration-induced apoptosis in the rat ventral prostate is associated with increased expression of genes encoding insulin-like growth factor-binding proteins-2, -3, -4 and -5. Endocrinology 139 807-810.

Oh Y, Muller HL, Pham H \& Rosenfeld RG 1993 Demonstration of receptors for insulin-like growth factor-binding protein-3 on Hs578T human breast cancer cells. Journal of Biological Chemistry 268 26045-26048.

Peehl DM, Skowronski RJ, Leung GK, Wong ST, Stamey TA \& Feldman D 1994 Antiproliferative effects of 1,25-dihydroxyvitamin D3 on primary cultures of human prostatic cells. Cancer Research $\mathbf{5 4}$ 805-810.

Peehl DM, Cohen P \& Rosenfeld RG 1996 Role of insulin-like growth factors in prostate biology. Journal of Andrology 17 2-4.

Rajah R, Valentinis B \& Cohen P 1997 Insulin-like growth factorbinding protein-3 induces apoptosis and mediates the effects of transforming growth factor- $\beta 1$ on programmed cell death through a p53- and IGF-independent mechanism. Journal of Biological Chemistry 272 12181-12188.

Rozen F, Yang X, Huynh HT \& Pollak M 1997 Antiproliferative action of vitamin-D-related compounds and insulin-like growth factor-binding protein-5 accumulation. Journal of the National Cancer Institute 89 652-656.

Schwartz GG \& Hulka BS 1990 Is vitamin D deficiency a risk factor for prostate cancer? Anticancer Research 10 1307-1311.
Schwartz GG, Oeler TA, Uskokovic MR \& Bahnson RR 1994 Human prostate cancer cells: inhibition of proliferation by vitamin D analogs. Anticancer Research 14 1077-1081.

Schwartz GG, Hill C, Oeler TA, Becich MJ \& Bahnson RR 1995 1,25-dihydroxy-16-ene-23-yne-vitamin $\mathrm{D}_{3}$ and prostate cancer cell proliferation in vivo. Urology 46 365-369.

Shimasaki S \& Ling N 1991 Identification and molecular characterization of insulin-like growth factor-binding proteins (IGFBP-1,-2,-3,-4,-5 and -6). Progress in Growth Factor Research 3 243-266.

Skowronski RJ, Peehl DM \& Feldman D 1995 Actions of vitamin D3 analogs on human prostate cancer cell lines: comparison with 1,25dihydroxyvitamin D3. Endocrinology 136 20-26.

Steiner MS 1995 Review of peptide growth factors in benign prostatic hyperplasia and urological malignancy. Journal of Urology 153 1085-1096.

Tenniswood M 1997 Apoptosis, tumour invasion and prostate cancer. British Journal of Urology 79 27-34.

Tonner E, Quarrie L, Travers M, Barber M, Logan A, Wilde C \& Flint D 1995 Does an IGF-binding protein (IGFBP) present in involuting rat mammary gland regulate apoptosis? Progress in Growth Factor Research 6 409-414.

deVos S, Holden S, Heber D, Elstner E, Binderup L, Uskokovic M, Rude B, Chen DL, Le J, Cho SK \& Koeffler HP 1997 Effects of potent vitamin D3 analogs on clonal proliferation of human prostate cancer cell lines. Prostate 31 77-83.

Wang X, Chen X, Akhter J \& Morris DL 1997 The in vitro effect of the vitamin D3 analogue EB1089 on a human prostate cancer cell line (PC-3). British Journal of Urology 80 260-262.

Received 12 June 1998

Revised manuscript received 16 September 1998 Accepted 28 September 1998 